\title{
Lumen
}

Selected Proceedings from the Canadian Society for Eighteenth-Century Studies

\section{'Altered, improved, copied, abridged': Alexandre d'Arblay's Revisions to Burney's Edwy and Elgiva}

\section{Peter Sabor}

Volume 14, 1995

URI : https://id.erudit.org/iderudit/1012514ar

DOI : https://doi.org/10.7202/1012514ar

Aller au sommaire du numéro

Éditeur(s)

Canadian Society for Eighteenth-Century Studies / Société canadienne d'étude du dix-huitième siècle

ISSN

1209-3696 (imprimé)

1927-8284 (numérique)

Découvrir la revue

Citer cet article

Sabor, P. (1995). 'Altered, improved, copied, abridged': Alexandre d'Arblay's Revisions to Burney's Edwy and Elgiva. Lumen, 14, 127-137.

https://doi.org/10.7202/1012514ar d'utilisation que vous pouvez consulter en ligne. 


\section{0. 'Altered, improved, copied, abridged': Alexandre d'Arblay's Revisions to Burney's Edwy and Elgiva}

In June 1793, six weeks before his marriage, Général Alexandre-JeanBaptiste Piochard, comte d'Arblay wrote to his fiancée Frances Burney - one of many letters in English and French that the couple had exchanged since their first meeting in January that year. Thanking Burney for the gift of a charming writing-case, $d$ 'Arblay assures her that he will put it to good use:

Je vous previens que si je suis un mediocre cooperateur pour les ouvrages sublimes que votre tête auguste doit enfanter, Je suis le plus determiné copiste (quand l'ouvrage me plait) ainsi que rien ne vous retienne. ${ }^{1}$

D'Arblay was true to his word. He had recently demonstrated his capacities as a copyist by transcribing parts of Madame de Staël's De l'influence des passions in May $1793 .{ }^{2}$ This was merely a five-finger exercise in comparison to his labours for Burney. In only six months in 1796, for example, he made two fair copies of Burney's longest novel, Camilla. As Joyce Hemlow notes, 'a manuscript of 1,370 pages in his small, clear, and upright hand stands as mute testimony of his care and devotion'; and since Burney used this copy to make numerous corrections, d'Arblay at once set to transcribing the entire five-volume work for a second time. ${ }^{3}$ Not surprisingly, in the midst of all this activity Burney wrote to her brother Charles that there would be delays in sending the final version to the publishers 'on account of poor M. d'A's head, which has retarded Copying. ${ }^{4}$

D'Arblay also made copies of two of Burney's plays: in 1795 her first tragedy, Edwy and Elgiva, which he transcribed in a volume of 67 pages, and in the early 1800s her final comedy, A Busy Day, transcribed in five notebooks of 370 pages. ${ }^{5}$ He was unable to copy Burney's final novel, The Wanderer (1814), since she completed it after her return to England while d'Arblay remained in France, but he again demonstrated his 
concern for her manuscripts by carefully assembling the mass of foul papers in a 'petite valise en cuir' and dispatching them to her at short notice. They were 'beautifully arranged ... you were unspeakably kind to send them as you found them,' as Burney wrote in a letter of August $1812{ }^{6}$ And in the last years of his life, 1815-18, d'Arblay copied into a letter-book parts of Burney's most important correspondence on family affairs and with famous persons. ${ }^{7}$

D'Arblay, however, was capable of more than merely transcribing his wife's manuscripts and arranging for their transportation. Before being forced to flee from France in 1792 as a Constitutionalist he had published a collection of occasional poems, as well as two pamphlets concerning a feud between members of the Garde nationale. ${ }^{8}$ In publishing his poetry he concealed his identity beneath a double disguise: attributing the verses to a pseudonymous 'Chevalier d'Anceny,' under the editorship of 'M. d'A**.' His self-effacement resembles that of Burney, who had taken great pains to conceal her authorship of Evelina (1778), and who would never acknowledge authorship of most of her plays. In one of her first accounts of her future husband, in a letter to her father of 16-19 February 1793, Burney described d'Arblay as 'passionately fond of literature, a most delicate critic in his own language, well versed in both Italian \& German, \& a very elegant Poet. ${ }^{9}$ Some years later, she told Dr. Burney that she was soon to receive 'some copies of some of the early effusions of my Partner,' brought from France to England by one of $\mathrm{d}^{\prime}$ Arblay's former amours, now a fellow émigrée. ${ }^{10}$

After his marriage to Burney, d'Arblay continued to write poetry, drama, translations and imitations of English authors, criticism, and treatises on a variety of subjects, but made no apparent attempt to publish any of these writings. The manuscripts, the majority of which are at the Berg Collection in New York and in the Osborn Collection at Yale, would fill several published volumes. They include a three-act comic opera, an elegant translation of Gay's Fables, and non-fictional pieces ranging from trenchant debates with his countrymen about the Revolution through a guide to the proper management of children to a highly technical note on the construction of hydraulic rams. Some of his poetry has been published in Joyce Hemlow's edition of Burney's Journals and Letters, such as his verses, written in May 1800, commemorating the death of Susanna Burney Phillips (4:411), and his imitation of Petrarchan sonnets on the power of love, sent to Burney in a letter of 24 January 1802 (5:142). In the last months of his life, d'Arblay wrote a considerable number of verses in his diary and in letters to Burney, including a weighty address 'A mon fils' to his son Alexander, and a thirteen-stanza ode on his own impending death, 'A L'Inevitable.'11 There is also, in the Berg Collection, a collection of observations entitled 'Morale, Philoso- 
phique, Politique,' based on the work of M. Le Clerc, which gives my paper its title: 'Altered, improved, copied, abridged. ${ }^{\prime 2}$ These are Burney's words, in a note describing the genesis of her husband's collection of observations, but they also characterise accurately his intentions in revising Edwy and Elgiva.

Not surprisingly, given his fondness for translating, imitating, and improving the works of others, D'Arblay also took an interest in Burney's writings that went beyond his role as faithful amanuensis. In the first year of their marriage he translated her tract entitled Brief Reflections Relative to the Emigrant French Clergy (1793). Publication of this translation, formally announced as 'preparing for the press' at the end of the pamphlet, was vexingly blocked by the appearance of a rival one, prepared by Louis-Mathias Barral, évêque de Troyes. ${ }^{13}$ D'Arblay also translated a sentimental ballad entitled 'Willy,' a story of two lost children saved by a dog, which Burney had composed at court in 1786 and revised shortly after her marriage ${ }^{14}$ In 1812 , when arranging the transportation of the manuscript of The Wanderer from France to England, $\mathrm{d}^{\prime}$ Arblay offered to translate the novel - although the translation did not materialize. ${ }^{15} \mathrm{D}^{\prime}$ Arblay also took an interest in the writings of Burney's brother James. In a letter of February 1803, he agreed to translate James's forthcoming work, A Chronological History of the Discoveries in the South Sea. ${ }^{16}$ Although the project was abandoned three years later, when d'Arblay realized that he had little hope of finding a publisher for his translation in France, he did translate about half of the first volume of James's 'interessant ouvrage. ${ }^{17}$ Few literary women have found partners so supportive as this. As Margaret Anne Doody notes in her fine account of the marriage, d'Arblay was 'gratifyingly able to refer to characters in Cecilia by name' and in general 'admired [Burney's] writings enormously.' Doody adds, alluding to Burney's labours in transcribing her father's History of Music, 'after years of copying her own work and her father's, Frances had acquired an amanuensis of her own. ${ }^{, 18}$

D'Arblay also wrote critical remarks on two of Burney's plays. In a manuscript note on The Siege of Pevensey, one of four unpublished tragic dramas that Burney began writing between 1788 and 1791, during five unhappy years of service at court, $d^{\prime}$ Arblay questioned whether the play could truly be considered a tragedy: 'Il me semble qu'on ne peut appeler tragédie une Piece dans la quelle il n'y a pas une goutte de sang versée.' D'Arblay was not, he continued, familiar with the historical source for Burney's play, and thus could not judge to what extent the text 'peut se plier aux changements que je crois qu' il est indispensable de faire. ${ }^{19}$ This last phrase is striking: 'mediocre cooperateur' though he may be, d'Arblay here plays the role of a critic able to judge what revisions are essential if a work by Burney is to succeed. 
D'Arblay's involvement with Edwy and Elgiva, which Burney had begun writing in 1788 and had revised in 1794, dates from January 1795. Charles Burney, Frances's brother, had arranged for the play to be produced at Drury Lane, with John Kemble and Sarah Siddons in the leading roles. Since only one copy of the manuscript existed, Charles asked d'Arblay to transcribe it. D'Arblay agreed to do so, assuring Charles that 'the copy shall be very soon ready. ${ }^{20}$ His letter, which has not been published, also reveals his concerns for the forthcoming production. Burney, he tells Charles, is eager to know of any criticisms of the play made by Charles, its 'principal reader' in the initial, pre-rehearsal reading, and by Siddons, the 'principal hearer.' She would thus be able to give the play 'a more theatrical perfection.' Burney and d'Arblay had, apparently, already heard about the inauspicious trial run. Hester Piozzi, drawing on an account from her friend Siddons, wrote maliciously in her diary of 'that worthy Gentleman her Brother's Pride' being wounded: 'when reading the Play in the Green Room before exhibitions - the Actors dropt silently off, one by one and left him all alone. ${ }^{21}$ In a postscript to his letter, d'Arblay urged Charles to inform Kemble, the manager as well as actor at Drury Lane, that Burney 'will consent to make any abridgement for the representation that he may judge proper, \& desires to know whether he wishes this to be done from her own opinion \& feelings, or whether he will send her a mark'd copy of the passages and parts he thinks may best be spared.'

Regrettably no criticisms or marked-up copy were ever sent to Burney. The actors, with the exception of Siddons, Kemble, and Robert Bensley, failed even to master their parts, and not surprisingly the play fared badly on stage, lasting for only one performance on 21 March 1795. Sarah Siddons herself condemned it, declaring that 'there never was so wretched a thing as Mrs D'arblaye's Tragedy,' as did Hester Thrale, who wrote of its being 'hooted off the Stage. ${ }^{22}$ Over twenty reviews in London newspapers for 22 and 23 March 1795, collected by Charles Burney, were also largely hostile, deploring the acting in particular but also criticizing various aspects of the play and regretting its excessive length. ${ }^{23}$ Burney herself, naturally, laid the blame squarely on the production, declaring in a letter of 15 April that 'the Piece was represented to the utmost disadvantage ... The Performers, too, were cruelly imperfect, \& made blunders I blush to have pass for mine. ${ }^{24}$ She also returned to the topic of d'Arblay's letter to Charles, noting that her plans to make 'divers corrections \& alterations' to the text had been frustrated by her absorption in her new baby and by ill health.

Burney had now to decide whether to abandon her play entirely or to revise it with a view towards further performances. Her literary friends gave her contradictory advice: Thomas Twining, for example, thought 
that she should put the play to rest, whereas Richard Cumberland, himself an experienced dramatist, ventured to 'risk his life' on the success of a revised version. ${ }^{25}$ Others, such as Richard Owen Cambridge and Elizabeth Montagu, advised Burney to publish the tragedy by subscription; Cambridge was 'sure the Names, \&c, would be splendid, etc. also the consequence. ${ }^{26} \mathrm{D}^{\prime}$ 'Arblay too lent his support, urging Burney to shrug off remarks from hostile critics: 'il faut qu'elle s'endurcisse d'avance contre les epines d'une carriere qu'elle a jusqu'à present trouvée semée de roses. ${ }^{27} \mathrm{He}$ also gave considerable practical assistance. While Burney made numerous changes to the manuscript of her copy of her play, d'Arblay both incorporated some of these changes in his transcript and listed all of them separately under the headings of the various parts. These corrigenda could thus be incorporated in the actors' individual copies, were the play to be staged again.

In transcribing Burney's revisions to Edwy and Elgiva, of course, d'Arblay did no more than he had promised in his pre-nuptial letter, acting as 'le plus determiné copiste.' But on this occasion he also went much further, for once becoming the 'cooperateur' that in his letter he had claimed he could not be and adding copious revisions of his own to Burney's text. These revisions he inserted between the lines of his original transcription, on blank pages interleaved between the written pages, and even on extra sheets attached to these blank pages. ${ }^{28}$ Many of his suggested revisions consist merely of indicating lines for possible deletion: given the audience's impatience with the original performance, there was much incentive to find ways to shorten the play. Occasionally too he suggests an alternative word or turn of phrase, although Burney's changes of this kind are much more frequent and more appropriate than his. Lacking a native command of English diction and blank-verse rhythm, d'Arblay was often unsuccessful in his attempts to improve Burney's verse. His proposal, for example, to condense two lines spoken by Edwy's counsellor Aldhelm, changing 'The grateful task of justifying virtue, / The pure delight of raising the oppress' $d$ ' (III, iii, 26-27) to 'The task of praising virtue \& raising the distress'd,' ignores the dictates of the iambic pentameter line. Similarly awkward is his compression of the following lines in another speech by Aldhelm:

His Rank superior tells thee what he lacks,

Equality; which Wedlock solely gives.

There he might taste fair Friendship's purest essence, -

Friendship (III, iv, 27-30) 
In D'Arblay's strangely truncated version, this becomes:

His Rank tells thee what he lacks

Equality - which Wedlock -

Friendship

Of greater interest and substance are the many passages where d'Arblay goes beyond slight verbal alterations, proposing extensive revisions to the action and characterization of Burney's play. The first such revision occurs in Act IV of Edwy and Elgiva. The secret marriage of King Edwy to his distant cousin Elgiva has been discovered by Dunstan, Abbot of Glastonbury, and other Church fathers, who pronounce the marriage void because canon law prohibited a union between relatives. Elgiva, having been seized by Dunstan's forces, has escaped, and Dunstan has been exiled by Edwy. At the beginning of Act IV, however, we learn that Elgiva has been captured again by Dunstan's supporters:

a fierce troop,

By Odo insitigated, Ernulf led,

The portals forc'd, and carried off the Princess.

(IV, i, 16-18)

Opposite these lines, on the interleaf of his copy, d'Arblay inserted a proposed revision that would radically alter the depiction of Elgiva:

Elgiva apprend le decret du Synode. Son desespoir, elle forme le dessein de se sacrifier pour sauver Edwy et lui conserver la puissance. Ses combats à ce sujet, Ernulf arrive, resistance des gardes à qui la reine est confiée \&c.

In Burney's text Elgiva forms no such plan to sacrifice herself to save Edwy and preserve his kingship. In Act II she defends the legality of her marriage to Edwy - 'My legal Lord! my wedded Husband!' (II, x, 21) - and in Act III she rejoices in their reconciliation; the idea of giving her a more active and complex role by making her consider a voluntary separation from Edwy moments before she is forcibly taken from him is d'Arblay's own, intriguing conception.

Other substantial revisions suggested by d'Arblay are all concentrated in the final act of the play - understandably, since this act is dominated by military matters, of which d'Arblay, a lifelong career soldier, had far greater knowledge than Burney. His recension begins with a note on the disposition of the armies opposing Edwy. Burney has erred, he observes, in making Ernulf, one of the rebel leaders, tell Dunstan that he has been encamped in the Vale of Evesham; rather, 
Burney should stress that Ernulf's outnumbered forces have been in flight from Edwy's, and that the meeting with Dunstan has taken place only because Ernulf has cleverly doubled back on his tracks. D'Arblay notes other such lapses too. Ernulf should not term the movement in which he participates a 'revolt' — 'revolution' would presumably be a better term - and Dunstan should not speak of travelling in 'disguise, unknown' when nothing had been done in the production to change his physical appearance.

In Burney's text, the military action of Act $V$ is interrupted by two scenes in which the dying Elgiva is aided first by her maid Eltruda and then by a peasant. D'Arblay observes, with a pointing hand in the margin to emphasize his remarks, that the scenes must be severely cut, but not deleted entirely 'parce qu'il est indispensable que l'auditoire sache que la Princesse existe encore.' Above all, $\mathrm{d}^{\prime}$ Arblay sought to ennoble Burney's heroine, as he had in his previous suggestion that she could offer to sacrifice herself to save Edwy's kingship. The peasant, in his recasting, is removed entirely; the appearance of so low a character beside the English queen was clearly not to d'Arblay's refined taste. (In her own revision of the play, Burney had already reduced the number of peasant assistants from three to one.) Reviewers of the stage production had poured scorn on an incongruous sofa on which Sarah Siddons as the wounded Elgiva rested in the forest. Thomas Campbell, Siddons's biographer, drawing on these accounts, wrote of the 'roars of mirth' that the 'elegant couch' occasioned; 'the solemn accents of the Siddons herself were no match for this ludicrous circumstance. ${ }^{29} \mathrm{D}^{\prime}$ Arblay suggests replacing the offending object with a tree-trunk on which Elgiva could rest, leaning against another tree and supported by Eltruda. Siddons, he notes, had been stretched out on her sofa like a dead woman; his Elgiva would be seen to be exhausted, seeking rest and shelter, but she would clearly be alive. We would see her 'Terreurs,' but when she hears the sounds of battle she would forget her own wound 'pour ne s'occuper que du dangers d'Edwy.' She would attempt to walk, supported by Eltruda, and when Edwy's men, victorious in battle, appeared on the scene, she would be carried on a sort of stretcher formed by the soldiers with their pikes. At this point too we would see Edwy's soldiers in action, 'traversant la foret en poursuivant les fuyards.'

In his recension, d'Arblay also wished to make Edwy a far more succesful military leader than he is in Burney's text. Like so many of her heroes - Orville in Evelina, Delvile in Cecilia, Edgar in Camilla, and Harleigh in The Wanderer, as well as the protagonists of several of her plays, such as Beaufort in The Witlings, Arnulph in Elberta, and Cleveland in A Busy Day - Edwy is distinguished by his incompetence: he is utterly unable either to protect his queen Elgiva or to achieve any success on the 
battlefield. D'Arblay's much more capable and dignified Edwy, in contrast, achieves splendid military victories in the first part of Act V; and though wounded he is born in triumph by his forces on flags captured from the enemy. D'Arblay even inserts an entire scene in which Edwy's faithful second-in-command Cerdic assures the victorious king that the blood of his soldiers has not been spilled in vain:

C'est l'humanité entière que vous vengez en vous elevant contre un empire dont le despotisme a trop longtems abusé des droits que la faiblesse lui a laissé s'arroger.

Edwy is reassured, and declares that he will never forget the gallant efforts of his loyal subjects, which make him insensible to the wound he has received. Only the news of his brother Edgar's treachery, not the force of the enemy, can undermine Edwy's powers. In D'Arblay's recension this is the turning-point that leads one of Edwy's supporters, Leofric, to kill himself in despair, and that likewise robs Edwy of his will to live. In Burney's text, Edwy reacts very differently to the news of his brother's revolt:

\section{Edgar? - My Brother? -}

Thou call'st me back to life! — I'm wondrous glad! -

Things the most savage suit my humour best.

Edgar, where art thou? - Glorious scenes of bloodshed

Fire with new energy my torpid mind. $-(\mathrm{V}$, xiv, 6-10)

A typically perverse Burney hero, Edwy is inspired to action only when such action is least appropriate; D'Arblay's more decorous Edwy, in contrast, is so distressed by his brother's perfidy that he no longer wishes to fight. In Burney's text, Edwy dies 'in mad defiance' as he rushes headlong and single-handed at the enemy. In d'Arblay's recension he would be slain by Dunstan in person, having refused to defend himself as a matter of principle.

Despite the pains that d'Arblay took in recasting parts of the tragedy and despite the encouragement of various friends, Burney did not attempt to publish Edwy and Elgiva or to have it revived on stage. She may have found the suggestion of seeking publication by subscription attractive, but in 1795 and 1796 she was carefully cultivating her subscription list for Camilla, and for her to have done the same for the play might have appeared indecorous. And when her thoughts turned to playwriting again after the publication of Camilla, she preferred to submit a new comedy, Love and Fashion, for stage production, rather than the now ten-year-old tragedy - knowing too that any comedy had a 
much greater chance of meeting with public approval. D'Arblay's belief that he would be at best a mediocre collaborator in Burney's literary productions thus proved to be true, and he never again attempted to revise her works in this fashion. It would, of course, have been difficult for Burney to have turned his prose directives in French into the formal English blank verse of her play, and it is equally difficult to envisage a Burney tragedy with a powerful, resolute hero such as d'Arblay's Edwy and a strong, self-sacrificing heroine such as his Elgiva.

Ironically, though, when Edwy and Elgiva was at last published in 1956, the copy-text was d'Arblay's transcription, rather than Burney's holograph. D'Arblay's revisons were printed as an appendix, albeit in mangled form, while Burney's own revisions in her copy were ignored. Something here is clearly amiss. D'Arblay's revisions to Edwy and Elgiva have an interest and charm of their own, but the revisions that Burney prepared independently should surely be given priority in any edition of her play. ${ }^{30}$ And while my paper has focused on Edwy and Elgiva as 'altered, improved, copied and abridged' by d'Arblay, I should like to see it and all of Burney's plays finding readers in a state unaltered, unimproved, and unabridged by any hand other than her own.

\section{PETER SABOR}

Université Laval

\section{Notes}

1 Letter of 16 June 1793; The Journals and Letters of Fanny Burney (Madame d'Arblay), ed. Joyce Hemlow et al, 12 vol. (Oxford: Clarendon Press, 1972-84) 2:163.

2 See Journals and Letters 2:163, n. 1.

3 Hemlow, The History of Fanny Burney (Oxford: Clarendon Press, 1957) 251. See also Camilla, ed. Edward A. Bloom and Lillian D. Bloom (Oxford: Oxford UP, 1972) xviii-xix. The penultimate draft of Camilla survives in the Berg Collection, New York Public Library.

4 Letter of 14 March 1796; Journals and Letters 3:163.

5 D'Arblay's transcription of Edwy and Elgiva survives in Emmanuel College, Cambridge, where it was deposited in the 1880 s by the then librarian, Evelyn Shuckburgh. Shuckburgh used this copy as the basis for his article 'Madame d'Arblay,' Macmillan's Magazine (February 1890) 291-98. The date of d'Arblay's transcription of A Busy Day, now in the Berg Collection, is uncertain; in her edition of the play, Tara Ghoshal Wallace is silent on this point ( $A$ Busy Day [New Brunswick, NJ: Rutgers UP, 1984]). D'Arblay probably made his copy after he and Burney were reunited in Paris in April 1802.

6 See d'Arblay's letter to Burney, 6 August 1812, and her reply, 9 August; Journals and Letters 6:688, 692-93. 
7 See Hemlow, Fanny Burney 386. The letter-book survives in the Osborn Collection, Yale University Library.

8 Opuscules du Chevalier d'Anceny, ou Anecdotes en vers recueillies et publiées par M. $d^{\prime} A^{* *}$ (1787); Récit exact du combat de M. de Bazoncourt, major de la 6e division (1790); Réponse à l'adresse de M. Collard au bataillon de Saint-Germain-l'Auxerrois (1790). Copies of these three rare works are in the Bibliothèque Nationale, Paris.

9 Journals and Letters 2:19.

10 Letter of 26 January 1797; Journals and Letters 3:256.

11 For excerpts from these poems, see Journals and Letters 10: 626, 680-83, 866, 868-71.

12 In her journal for 1815, Burney describes her husband's work on these papers during his final illness: 'to look these over was the chief occupation of my ever mind-employed Invalid - ever! to his last hour, when not impeded by sufferings insupportable' (Journals and Letters 8:523). M. Le Clerc, although said to be a general by Burney, has not been further identified.

13 See Brief Reflections 27, and Journals and Letters 3:51, n. 3-4. Neither translation apparently was ever published.

14 See Hemlow, Fanny Burney 224. D'Arblay's translation survives in two transcriptions, at the Osborn and Berg collections; Burney's original is not known to be extant.

15 See Burney's letter to d'Arblay of 9 August 1812; Journals and Letters 6:694.

16 D'Arblay to James Burney; Journals and Letters 5:409.

17 D'Arblay to James Burney, 10 October 1806; Journals and Letters 6:537.

18 Doody, Frances Burney: The Life in the Works (Cambridge: Cambridge UP, 1988) 200, 203.

19 Note on the cover of Act III of The Siege of Pevensey, ms. in the Berg Collection.

20 Letter of 12 January 1795, Osborn Collection. See also Edwy and Elgiva, ed. Miriam J. Benkovitz (New York: Shoe String Press, 1957) x. Burney's holograph of the play is in the Berg Collection. A copy made by a Drury Lane scribe from d'Arblay's transcription, submitted to the Lord Chamberlain for license on 9 March 1795, is in the Larpent Collection, Huntington Library.

21 Thraliana, ed. Katharine C. Balderston, 2nd ed., 2 vol. (Oxford: Clarendon Press, 1951) 2:916.

22 Letter from Siddons to Piozzi, 21 March 1795; Thraliana 2:916, n. 1.

23 Excerpts from some of these reviews, which survive in the Burney Collection, British Library, are printed in Journals and Letters 3:366-67. See also Peter Sabor, 'The Rediscovery of Frances Burney's Plays,' Lumen 13 (1994) 145-56.

24 Journals and Letters 3:99-100.

25 See Journals and Letters 3:105, n. 4, and 110.

26 Journals and Letters 3:110.

27 Letter of c. 22 March 1795; Journals and Letters 3:97.

28 D'Arblay's proposed revisions were printed, with numerous errors, in an Appendix to Benkovitz's edition of Edwy and Elgiva. My quotations from d'Arblay are from the manuscript at Emmanuel College; quotations from Burney's text are 
from my edition of the play in The Complete Plays of Frances Burney (London: Pickering and Chatto, 1995).

29 Campbell, The Life of Mrs. Siddons (1834; rpt. New York: Blom, 1972) 267. This account is taken from reviews in the Morning Herald and the Whitehall Evening Post, 23 March 1795.

30 My own text of the play, in The Complete Plays of Frances Burney, is based on Burney's final recension, with textual notes recording her (but not d'Arblay's) revisions. 